\title{
Adding straw to a total mixed ration and the method of straw inclusion affects production and eating behaviour of lactating dairy cows
}

D J Humphries ${ }^{1}$, D E Beever ${ }^{2}$, C K Reynolds ${ }^{1}$

${ }^{1}$ University of Reading, Reading, Berkshire, United Kingdom, ${ }^{2}$ Richard Keenan and Co., Stoneleigh, Warwickshire, United Kingdom

Email: c.k.reynolds@reading.ac.uk

Introduction The inclusion of straw in the diet of lactating dairy cows as a source of physically effective fibre may benefit rumen function and production. By stimulating chewing and rumination, effective fibre should promote a more stable rumen by preventing large variations in rumen $\mathrm{pH}$ that can occur when cows consume high levels of readily fermentable carbohydrate (Beauchemin et al., 2008). Whilst the concept of including limited amounts of straw in milking rations is accepted as being nutritionally sound, there is limited scientific proof available (Ferris et al., 2000). Further to this, chop length of the straw as well as the amount included in the ration may be crucial if expected benefits are to be achieved without compromising production or feed efficiency. Our objective was to evaluate the effects of adding straw to a total mixed ration (TMR) and the method of straw inclusion (and resulting differences in straw chop length) on feed intake, eating and rumination activity, rumen $\mathrm{pH}$, milk yield, and milk composition of lactating dairy cows.

Materials and methods Nine multiparous lactating Holstein-Friesian cows averaging 43 litres milk/d were used in a replicated $3 \times 3$ Latin Square design experiment with 3 wk periods. Treatments were a control TMR prepared using a horizontal mixer (C) and two treatment rations containing wheat straw added using a horizontal mixer (horizontal straw; HS) or a vertical mixer that gave a longer straw chop length (vertical straw; VS). The C TMR contained on a dry matter (DM) basis: $37 \%$ maize silage, $18 \%$ grass silage, and $45 \%$ concentrates. For treatments HS and VS straw was added to the C TMR at $4 \%$ of ration DM, diluting other ingredients. Measurements were obtained in the last week of each period. Feeding (6 cows) and rumination behaviour ( 3 cows) was monitored using computerized feed weight and jaw movement recording, respectively and rumen $\mathrm{pH}(3$ cows) was monitored using indwelling probes. Data were analyzed using Mixed Models procedures and a model testing fixed effects of square (when appropriate), diet, period and diet by period interaction and random effects of cow. Orthogonal contrasts tested overall effects of straw and effect of mixer type.

Results Measurements of particle size distribution using a Penn State Separator found no difference between the C and HS rations, but a greater percentage of long particles $(\mathrm{P}<0.01)$, and fewer medium $(\mathrm{P}<0.02)$ and small $(\mathrm{P}<0.02)$ particles for the VS ration. Average particle size was 12.2, 11.7, and $14.2 \mathrm{~mm}$ for C, HS, and VS rations, respectively. Cows fed the VS ration had lower DM intake (DMI), milk yield, and milk protein concentration and yield than for the C and HS rations (Table 1). Cows fed straw spent more time eating, thus had a lower eating rate compared to C, and these effects were greater for VS than for the HS ration (Table 1). In addition, cows fed straw consumed fewer meals of 4 to $8 \mathrm{~kg}$ fresh weight, compared to the $\mathrm{C}$ ration (3.1 vs. 2.8 meals/d; $\mathrm{P}<0.001)$. There were no effects of ration on rumination activity or rumen $\mathrm{pH}$, but time below $\mathrm{pH} 6.0$ was numerically lower for HS (5.28 h) compared to C (6.99 h) or VS (7.28 h).

Table 1 Effects of straw inclusion and method of inclusion on intake (DM) milk yield and composition.

\begin{tabular}{|c|c|c|c|c|c|c|c|}
\hline & \multicolumn{3}{|c|}{ Ration } & \multirow[b]{2}{*}{ SEM } & \multicolumn{3}{|c|}{$\bar{P}<<^{1}$} \\
\hline & $\mathrm{C}$ & $\mathrm{HS}$ & $\mathrm{VS}$ & & Ration & Straw & Mixer \\
\hline Intake (kg) & $24.1^{\mathrm{a}}$ & $23.4^{\mathrm{a}}$ & $22.5^{b}$ & 0.64 & 0.006 & 0.006 & 0.040 \\
\hline Milk yield (kg) & $40.8^{\mathrm{a}}$ & $40.3^{\mathrm{a}}$ & $39.3^{\mathrm{b}}$ & 1.71 & 0.017 & 0.027 & 0.043 \\
\hline Fat $(\mathrm{g} / \mathrm{kg})$ & $36.0^{\mathrm{ab}}$ & $35.2^{\mathrm{a}}$ & $36.5^{\mathrm{b}}$ & 1.78 & 0.113 & 0.840 & 0.041 \\
\hline Protein $(\mathrm{g} / \mathrm{kg})$ & $32.1^{\mathrm{a}}$ & $31.7^{\mathrm{b}}$ & $31.1^{\mathrm{c}}$ & 0.82 & 0.001 & 0.001 & 0.001 \\
\hline Fat (g/day) & 1460 & 1427 & 1418 & 83.1 & 0.303 & 0.137 & 0.735 \\
\hline Protein (g/day) & $1288^{\mathrm{a}}$ & $1253^{\mathrm{a}}$ & $1208^{b}$ & 46.8 & 0.006 & 0.006 & 0.050 \\
\hline Time eating, $\mathrm{min} / \mathrm{d}$ & $237^{\mathrm{a}}$ & $261^{b}$ & $291^{c}$ & 14.9 & 0.001 & 0.001 & 0.001 \\
\hline Eating rate, g DM/min & $0.096^{\mathrm{a}}$ & $0.087^{\mathrm{b}}$ & $0.078^{\mathrm{c}}$ & 0.0066 & 0.001 & 0.001 & 0.011 \\
\hline Average rumen $\mathrm{pH}$ & 6.15 & 6.18 & 6.14 & 0.087 & 0.778 & 0.827 & 0.550 \\
\hline
\end{tabular}

${ }^{1}$ Probability of no effect of ration, addition of straw (C vs. HS and VS), or the mixer used (HS vs. VS).

${ }^{a, b, c}$ Values with different superscripts are statistically different $(\mathrm{P}<0.05)$

Conclusions The results of the present study demonstrate that when rations prepared using identical ingredients, in the same proportions, are processed to give differing chop length there are differences in the responses of feed intake and milk production to added straw. Adding straw to a TMR at $4 \%$ of ration DM reduced feed intake and milk yield when the straw was processed to give a longer chop length (VS). These differences in production response to straw incorporation into a TMR can be attributed in part to differences in particle size distribution and subsequent effects on total nutrient intake.

Acknowledgements The authors gratefully acknowledge funding from Richard Keenan and Co. Ltd

\section{References}

Beauchemin,K. A., L. Eriksen, P. Nørgaard, and L. M. Rode. 2008. Short Communication: Salivary secretion during meals in lactating dairy cattle. Journal of Dairy Science 91, 2077-2081.

Ferris, C. P., D.C. Patterson, F. J. Gordon and D. J. Kilpatrick. 2000. The effects of incorporating small quantities of straw in grass/grass silage-based diets for dairy cows. Grass Forage Science 55, 146-158. 